IEA/SHC

Task 57, Subtask B

Draft proposals for new test procedures

B3: Final Draft

\title{
Draft proposals for Test methods and requirements for building integrated solar collectors and systems
}

Zhang Lei, Gu Xiuzhi

China Architecture Design \& Research Group (CADRG)

China National Engineering Research Center for Human Settlements (CNERCHS)

28 September 2018 


\section{Contents}

1. Scope

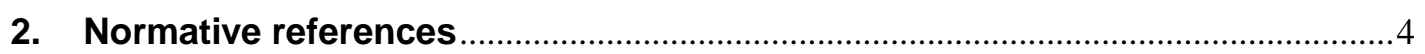

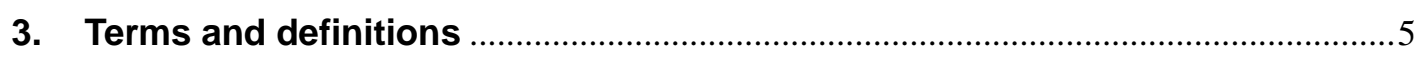

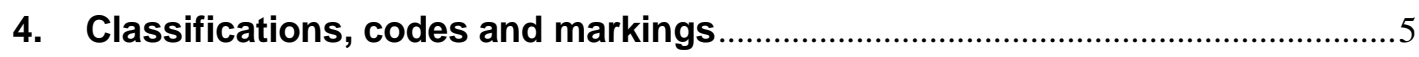

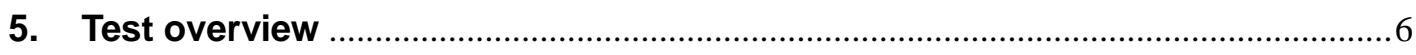

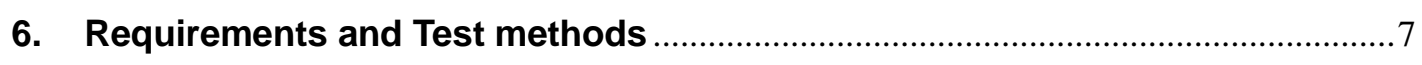

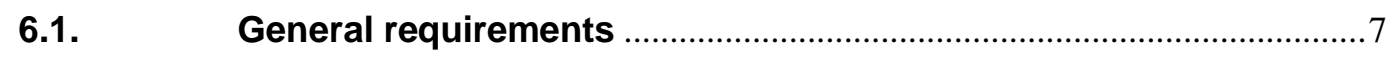

6.2. Flat plate solar thermal components ....................................................

6.3. Evacuated tube solar thermal components ....................................

6.4. Building performance of solar thermal component ............................

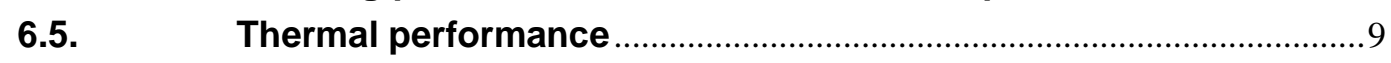

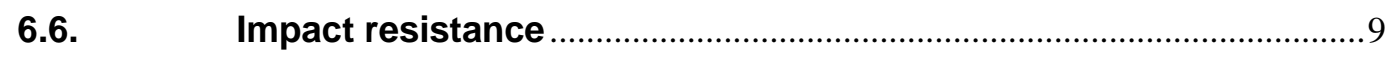

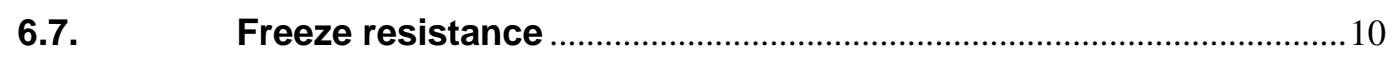

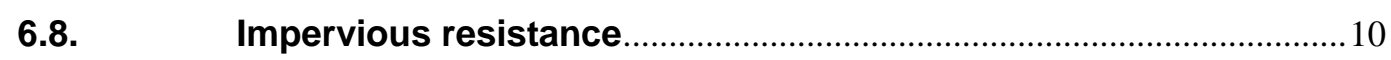

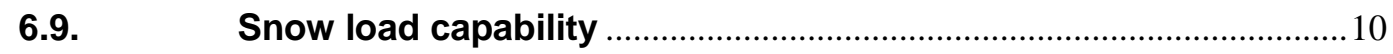

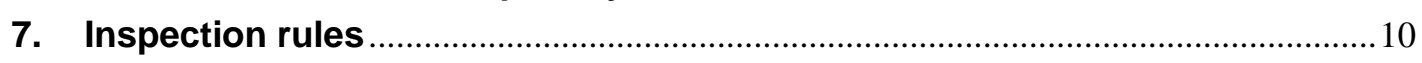

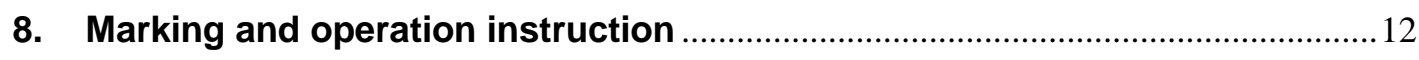

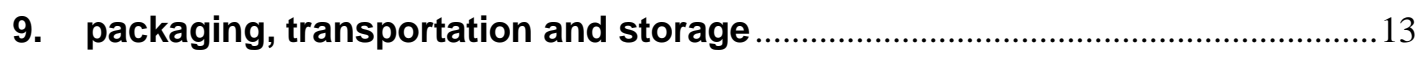

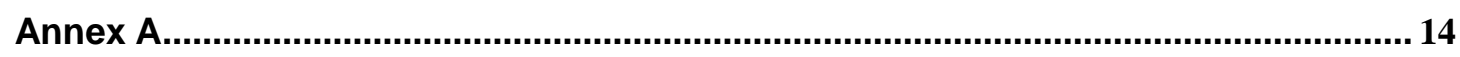

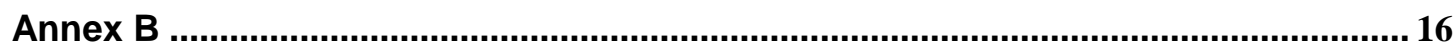

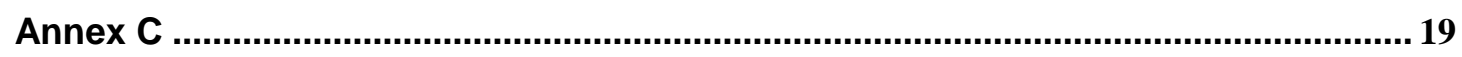

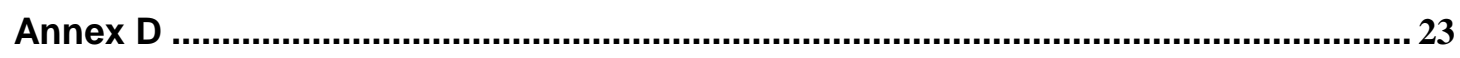

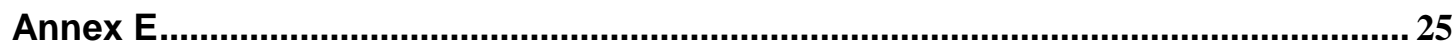

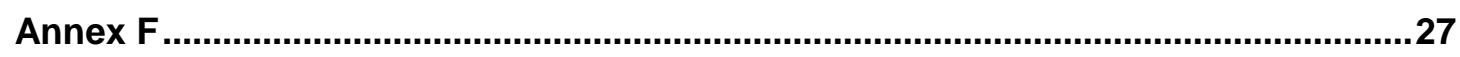

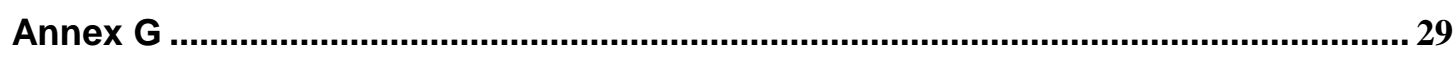




\section{Forward}

Responsible drafting departments include: China Architecture Design \& Research Group, China National Engineering Research Center for Human Settlement and Chinese Renewable Energy Society and Special Committee of Solar Buildings, Cres. Participating drafting departments include: Beijing Building Materials Testing Academy Co., Ltd., Fujian Academy of Building Research, China Singyes Solar Technologies Holdings Limited, Beijing four seasons Mu Song Solar Energy Technology Group Co., Ltd., Beijing Tianyun Solar Technology Development Co., Ltd., Beijing Jiu Yang Industry Co., Ltd., Shaanxi Risheng New Energy Technology Co.,Ltd., International Copper Association, Ltd.

The specification's major drafters include:Zhang Lei, Gu Xiuzhi, Xie Zhuwen, Tan Junyi, Zhu Ning, Fang Fengjie, Zhao Guohua, Zhu Yajian, Ju Xiaolei, Xia Jingjing, Huang Junpeng. 


\section{Test methods and requirements for building integrated solar collectors and systems}

\section{Scope}

This standard specifies the terms and definitions, classifications, codes and markings, general requirements, requirements and test methods, inspection rules, signs, marking and operation instruction, packaging, transportation and storage of solar thermal components for building.

This standard is applicable to solar thermal components for industrial and civil usage.

\section{Normative references}

Following documents are essential for this standard. For reference documents with date, only dated edition is applicable. For reference documents without date, the latest edition (including all amendments) is applicable.

ISO 140-3 Acoustics-Measurement of sound insulation in buildings and of building elements part 3: Laboratory measurements of airborne sound insulation of building elements

ISO 780 Packaging - Pictorial marking for handling of goods

ISO 8990: 1994 (E) Thermal insulation - Determination of steady-state thermal transmission properties using the calibrated and guarded hot boxes

ISO 9806 Solar energy - Solar thermal collectors - Test methods

ISO 11600 Building construction - Jointing products - Classification and requirements for sealants

ISO 22975 -1 Solar energy - Collector components and materials - Part 1: Evacuated tubes - Durability and performance

BS EN 13050:2011 Test method of air permeability,watertightness, wind load resistance performance for curtain walls

BS EN 13501-1-2007+A1-2009 Fire classification of construction products and building elements

EN 490 Concrete roofing tiles and fittings for roof covering and wall cladding - Product specifications

EN 1932 External blinds and shutters - Resistance to wind loads - Method of testing

AS 4020-2005 Standard for safety evaluation of equipment and protective materials in drinking water system 


\section{Terms and definitions}

Following terms and definitions are applicable for this standard.

\subsection{Solar Thermal Component}

Solar collectors and solar water heaters that comply with the building performance requirement and could be used as building materials or building components

\section{Classifications, codes and markings}

\subsection{Classifications and codes}

\subsubsection{Classified by collector type}

a) Flat plate solar thermal components, codenamed F;

b) Evacuated thermal components, codenamed E.

\subsubsection{Classified by mounting position}
a) Roof solar thermal components, codenamed R;
b) Wall solar thermal components, codenamed W;
c) Breast board solar thermal components, codenamed B;
d) Sunshade solar thermal components, codenamed S.

\subsection{Marking method}

The marking of solar thermal components shall follow the requirement of Figure 1

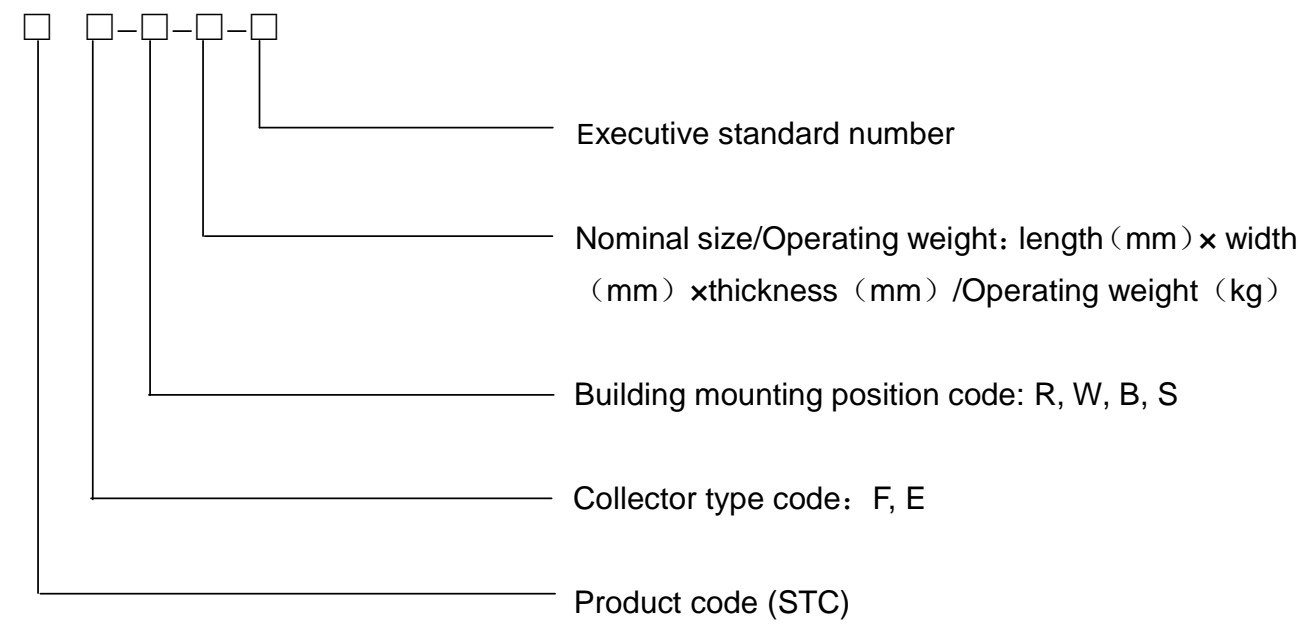

Figure 1 Marking method of solar thermal components

Example: Marking of Flat plate roof solar thermal components with nominal size of $2000 \mathrm{~mm} \times 1000 \mathrm{~mm} \times 80 \mathrm{~mm}$ and operating weight of $50 \mathrm{~kg}$. 
STC P $-R-2000 \times 1000 \times 80 / 50-J G / T 493-2016$

\section{Test overview}

Requirement and test for solar thermal components for building are specified in Clause 5. The tests shall be performed according to Table 1 .

Table 1 - Test list

\begin{tabular}{|l|l|}
\hline Clause & Test \\
\hline 6.1 & General requirements \\
\hline 6.2 & Flat plate solar thermal components \\
\hline 6.3 & Evacuated tube thermal components \\
\hline 6.4 & Building performance of solar thermal components \\
\hline 6.5 & Thermal performance \\
\hline 6.6 & Impact resistance \\
\hline 6.7 & Freeze resistance \\
\hline 6.8 & Impervious resistance \\
\hline 6.9 & Snow load capacity \\
\hline
\end{tabular}

\section{Requirements and Test methods}

\subsection{General requirements}

a) Solar thermal components for building shall coordinate with the building modulus. Nominal size shall comply with the size requirement of mounting position of building.

b) Materials of solar thermal components shall comply with following requirement:

-The physical, chemical and mechanical property shall match with each other.

-Load components shall comply with the stiffness, strength and weather-ability requirement of mounting position.

-Corrosion resistance performance of anti-corrosive material shall be well. The appropriate anti-corrosion measures should be used.

-Surface material shall be surface treated. The specular reflection ratio of visible light of the surface shall not be greater than 0.3.

-The welding line strength of welding material shall be adapted to raw material.

-The sealing materials in weather resistance shall be guaranteed not to deform after cold draw, hot pressing, exposure to sunshine and immersion.

-Do not use foaming material with asbestos and chlorofluorocarbons (CFCs) as thermal insulation material. The heat resistance shall not be lower than $200^{\circ} \mathrm{C}$. And the heat conductivity coefficient shall not be greater than $0.05 \mathrm{w} /(\mathrm{m} \cdot \mathrm{k})$.

c) Solar thermal components shall be easy to replace and maintain. When being 
used as building component, the structure durability of solar thermal components shall comply with the endurance requirement of replaced building components.

d) The thermal components shall meet the requirements for the combustion performance grading and mechanical properties of the building materials or building components for substitute parts.

e) The materials inside the thermal components in contact with the domestic hot water in hygiene property shall be guaranteed not to destroy the quality of the domestic hot water.

f) The fragile part of solar thermal components shall have obvious indication.

g) Solar thermal components that connects with building by metal stents or other metal components shall have reliable lightning protection and grounding design.

h) When being used as building component, the heat transfer coefficient shall comply with the requirement of building components that being replaced. When being used as building material, the heat conductivity coefficient shall comply with the requirement of building components that being replaced.

i) Solar thermal components shall comply with the load requirement of building materials or building components that being replaced.

j) The frame of roof solar thermal components and wall solar thermal components shall take measure of thermal barrier.

k) The roof thermal components and wall thermal components shall meet the requirements for airborne sound insulation of the building materials or building components for substitute parts.

\subsection{Flat plate solar thermal components}

\subsubsection{Requirement}

The appearance, pressure tightness, stiffness, strength, thermal performance, stagnation, exposure, external thermal shock, internal thermal shock, rain penetration, pressure drawdown of flat plate solar thermal component shall comply with the requirement of ISO 9806.

\subsubsection{Test method}

All performance of flat plate solar thermal components shall be tested according to ISO 9806.

\subsection{Evacuated tube solar thermal components}

\subsubsection{Requirement}

The appearance, pressure tight, stiffness, strength, thermal performance, stagnation, 
exposure, external thermal shock, internal thermal shock, rain penetration, pressure drawdown of evacuated tube solar thermal components shall comply with the requirement of ISO $22975-1$.

\subsubsection{Test method}

All performance of evacuated tube solar thermal components shall be tested according to ISO $22975-1$.

\subsection{Building performance of solar thermal components}

\subsubsection{Requirement}

Building performance of solar thermal components shall comply with the requirement of Table 2.

Table 2: Building performance requirement of solar thermal components

\begin{tabular}{|c|c|c|c|c|c|c|}
\hline \multirow{2}{*}{$\begin{array}{l}\text { Building } \\
\text { performance } \\
\text { requirement }\end{array}$} & \multicolumn{2}{|c|}{$\begin{array}{l}\text { Roof solar thermal } \\
\text { components }\end{array}$} & \multicolumn{2}{|c|}{$\begin{array}{l}\text { Wall solar thermal } \\
\text { components }\end{array}$} & \multirow{2}{*}{$\begin{array}{l}\text { Breast board } \\
\text { solar thermal } \\
\text { components }\end{array}$} & \multirow{2}{*}{$\begin{array}{c}\text { Sunshade solar } \\
\text { thermal } \\
\text { components }\end{array}$} \\
\hline & $\begin{array}{l}\text { Use as } \\
\text { component }\end{array}$ & $\begin{array}{l}\text { Use as } \\
\text { material }\end{array}$ & $\begin{array}{l}\text { Use as } \\
\text { component }\end{array}$ & $\begin{array}{l}\text { Use as } \\
\text { material }\end{array}$ & & \\
\hline $\begin{array}{l}\text { Thermal } \\
\text { performance }\end{array}$ & $\sqrt{ }$ & 0 & $\sqrt{ }$ & 0 & - & - \\
\hline $\begin{array}{c}\text { Impact } \\
\text { performance }\end{array}$ & $\sqrt{ }$ & $\sqrt{ }$ & $\sqrt{ }$ & $\sqrt{ }$ & $\sqrt{ }$ & $\sqrt{ }$ \\
\hline $\begin{array}{c}\text { Freeze } \\
\text { performance }\end{array}$ & $\sqrt{ }$ & $\sqrt{ }$ & 0 & 0 & $\sqrt{ }$ & $\sqrt{ }$ \\
\hline $\begin{array}{l}\text { Impervious } \\
\text { performance }\end{array}$ & $\sqrt{ }$ & $\sqrt{ }$ & $\sqrt{ }$ & $\sqrt{ }$ & - & - \\
\hline $\begin{array}{l}\text { Snow load } \\
\text { capacity }\end{array}$ & - & - & - & - & - & $\sqrt{ }$ \\
\hline
\end{tabular}

\subsubsection{Test method}

All building performance of solar thermal shall be tested according to Table 3 .

Table 3: Building performance test method of solar thermal components

\begin{tabular}{|c|c|c|c|c|c|c|}
\hline \multirow{2}{*}{$\begin{array}{l}\text { Building } \\
\text { performance } \\
\text { requirement }\end{array}$} & \multicolumn{2}{|c|}{$\begin{array}{l}\text { Roof solar thermal } \\
\text { components }\end{array}$} & \multicolumn{2}{|c|}{$\begin{array}{l}\text { Wall solar thermal } \\
\text { components }\end{array}$} & \multirow{2}{*}{$\begin{array}{c}\text { Breast board } \\
\text { solar thermal } \\
\text { components }\end{array}$} & \multirow{2}{*}{$\begin{array}{c}\text { Sunshade solar } \\
\text { thermal } \\
\text { components }\end{array}$} \\
\hline & $\begin{array}{l}\text { Use as } \\
\text { component }\end{array}$ & $\begin{array}{l}\text { Use as } \\
\text { material }\end{array}$ & $\begin{array}{l}\text { Use as } \\
\text { component }\end{array}$ & $\begin{array}{l}\text { Use as } \\
\text { material }\end{array}$ & & \\
\hline $\begin{array}{l}\text { Thermal } \\
\text { performance }\end{array}$ & 6.5 .2 & 6.5 .2 & 6.5 .2 & 6.5 .2 & - & $\longrightarrow$ \\
\hline $\begin{array}{c}\text { Impact } \\
\text { performance }\end{array}$ & 6.6.2(a) & 6.6.2(a) & 6.6.2(b) & $6.6 .2(b)$ & 6.6.2(c) & 6.6.2(a) \\
\hline $\begin{array}{l}\text { Freeze } \\
\text { performance }\end{array}$ & 6.7 .2 & 6.7 .2 & 6.7 .2 & 6.7 .2 & 6.7 .2 & 6.7 .2 \\
\hline $\begin{array}{l}\text { Impervious } \\
\text { performance }\end{array}$ & 6.8 .2 & 6.8 .2 & 6.8 .2 & 6.8 .2 & - & \\
\hline
\end{tabular}




\begin{tabular}{|c|c|c|c|c|c|c|}
\hline $\begin{array}{c}\text { Snow load } \\
\text { capacity }\end{array}$ & $6.9 .2(\mathrm{a})$ & $6.9 .2(\mathrm{a})$ & - & - & - & $6.9 .2(\mathrm{~b})$ \\
\hline
\end{tabular}

\subsection{Thermal performance}

\subsubsection{Requirement}

The heat transfer coefficient of the roof thermal components and wall thermal components shall meet the national requirements for heat transfer coefficient of the roof and wall in the state where the project is located.

\subsubsection{Test method}

Thermal performance of roof solar thermal components and wall solar thermal components shall be tested according to ISO 8990: 1994 (E).

Note: There is the concept of $g$-value which is to be mirrored under the work item here in TC 180.

\subsection{Impact resistance}

\subsubsection{Requirement}

a) Roof solar thermal components and sunshade solar thermal components shall bear the hail impact test of requirement.

b) The impact resistance of the thermal components of the wall of public buildings with large personnel flow density or for the activities of adolescents and young children shall meet the following requirements: If the indoor side impact energy is $900 \mathrm{~N} \cdot \mathrm{m}$, then the landing height of the impactor is $2000 \mathrm{~mm}$; if the indoor side impact energy is $500 \mathrm{~N} \cdot \mathrm{m}$, then the landing height of the impactor is 1100 $\mathrm{mm}$.

c) The soft heavy body impact resistance of the thermal components of the fence shall meet the following requirements: Use $45 \mathrm{~kg}$ soft heady body with the impact energy $E$ of $300 \mathrm{~N} \cdot \mathrm{m}$ to impact the handrail and the fence in order. The measured relative horizontal displacement of the handrail after each impact shall not be greater than $h / 25$, and the connection parts shall have no phenomena of relaxation or shedding.

d) The hard heavy body impact resistance of the thermal components of the fence shall meet the following requirements: Use a solid steel ball with weight of $1040 \mathrm{~g} \pm 10 \mathrm{~g}$ to impact the glass fence of guard bar or metal plate fence by swinging the arm at the lading height of $1.2 \mathrm{~m}$, and the fence shall have no fragment shedding, or various connection parts have no phenomena of relaxation or shedding.

\subsubsection{Test method}

a) Roof solar thermal components and sunshade solar thermal components shall 
be performed the hail impact test according to Annex $\mathrm{A}$.

b) Wall solar thermal components shall be performed the impact test according to Annex B.

c) Wall solar thermal components shall be performed the soft object impact resistance and hard object impact resistance test according to Annex $C$ and Annex D.

\subsection{Freeze resistance}

\subsubsection{Requirement}

The appearance and performance shall not change after freeze resistance test.

\subsubsection{Test method}

Solar thermal components shall be tested according to Annex E.

\subsection{Impervious resistance}

\subsubsection{Requirement}

The back of solar thermal components shall not leak after impervious resistance test.

\subsubsection{Test method}

Solar thermal components shall be tested according to Annex F.

\subsection{Snow load capability}

\subsubsection{Requirement}

a) The snow load of thermal components of the roof and the construction maintenance load shall meet the national requirements for the roof snow load of the state where the project is located.

b) In case of use in the cold regions or severe cold regions, the snow load test shall be conducted on the sunshade components having the inclined angle with the horizontal plane of less than $60^{\circ}$. The snow load value shall be determined by both parties based on the local basic snow pressure and snow distribution coefficient.

\subsubsection{Test method}

a) Manufacturer of roof solar thermal components shall provide the calculation of snow load capability and maintenance load capability, which shall be checked according to the construction situation by Architecture Design Company with relevant qualification.

b) Snow load capability of sunshade solar thermal components shall be tested according to Annex G. 


\section{Marking and operation instruction}

\subsection{Marking}

There shall be obvious and permanent marking on the product. Marking shall include at least:
a) Trademark and name of manufacturer
b) Name and model of product
c) Daylighting area and nominal working pressure
d) Batch number and serials number
e) Operating weight and nominal size
f) Inspection mark
g) Production date

Marking on package case shall include following content:
a) Trademark and name of manufacturer
b) Address and contact information of manufacturer
c) Model, production date and batch number
d) Gross weight, net weight and amount of product
e) Size of package case and allowable stacking layer.
f) Damp proof, shockproof and layer weight.

\subsection{Content of operation instruction}
a) Product technology parameter;
b) Product installation instruction;
c) Operating and maintenance instruction, failure reason and treatment measure;
d) Warranty certificate;
e) Container loading list.

\section{8. packaging, transportation and storage}

\subsection{Packaging}

Products shall be packaged in cases.

The marking on package shall comply with the requirement of ISO 780 .

\subsection{Transportation}

In the process of load, unload and transportation, products shall be prevent from jolt, shock, damp and rain. 
8.3. Storage

Products shall be stored in ventilated and dry warehouse.

Products shall not be stored with combustibles and corrosive chemicals. 


\section{Annex A}

(Normative)

\section{Test method of hail impact test of solar thermal components for building}

\section{Or}

\section{ISO EN 9806}

\section{A.1 Test appliance and test procedure}

A.1.1 Install the solar thermal component horizontally or vertically on the support frame (see Graph A.1), using steel ball to simulate the hail shock. Support frame shall be sturdy enough to ignore the slight deformation of impact.

A.1.2 If the component is installed horizontally, the steel ball shall fall vertically. And if the component is installed vertically, use pendulum bob to make horizontal strike. Drop height $\mathrm{H}$ is measured from the vertical distance of the release point to impact point on horizontal surface. The distance of the impact point to the component center shall not be greater than $5 \mathrm{~cm}$.
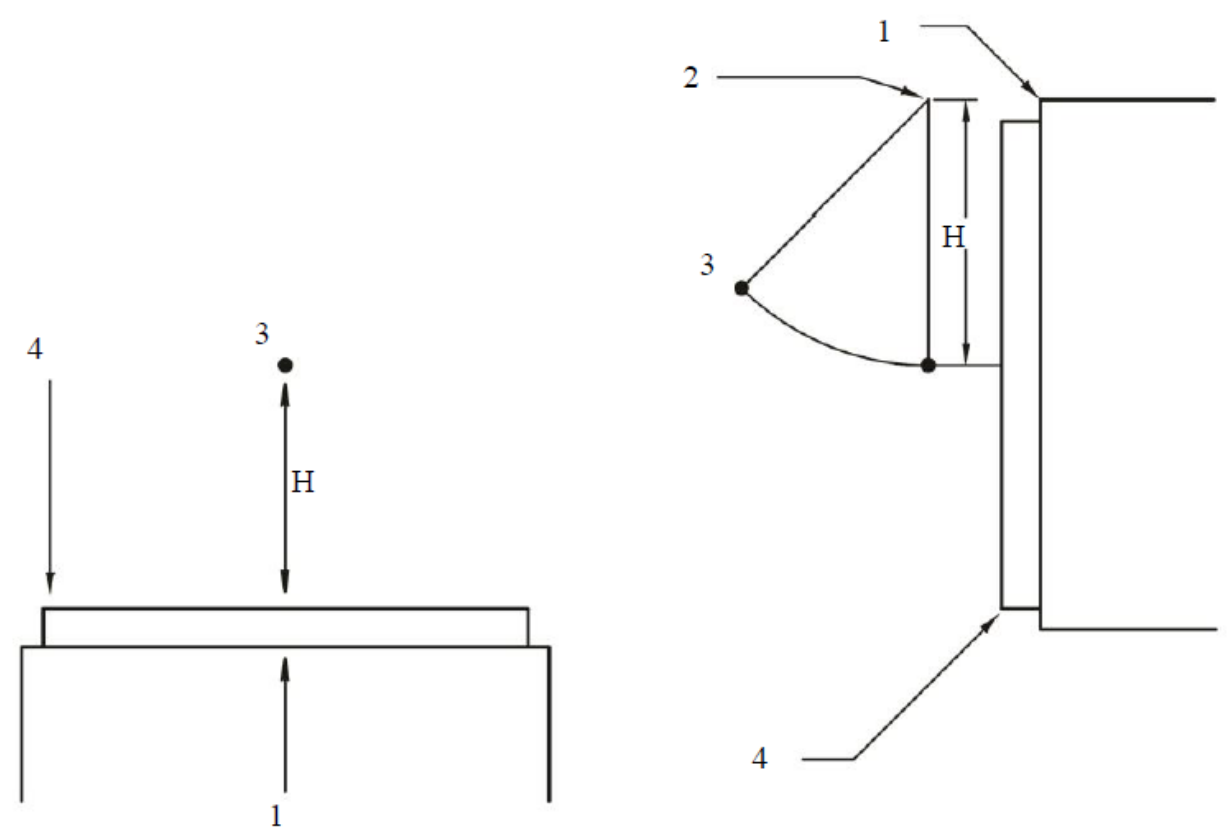
a) Vertical impact test diagram
b) Horizontal impact test diagram

Note: 
1-support frame; 2- pendulum bob; 3-Steel ball; 4- Solar thermal component

Figure A.1: Diagram of hail impact test

A.1.3At first test height of $0.4 \mathrm{~m}$, steel ball shall hit the component for10times; then at second test height of $0.6 \mathrm{~m}$, steel ball shall hit the component 10times; continue the test until the height of $2.0 \mathrm{~m}$. Stop the test when the height reaches $2.0 \mathrm{~m}$ or component damaged.

\section{A.2 Test condition}

A.2.1 Quality of steel ball: $150 \mathrm{~g} \pm 10 \mathrm{~g}$.

A.2.2 Test height $H: 0.4 \mathrm{~m}, 0.6 \mathrm{~m}, 0.8 \mathrm{~m}, 1.0 \mathrm{~m}, 1.2 \mathrm{~m}, 1.4 \mathrm{~m}, 1.6 \mathrm{~m}, 1.8 \mathrm{~m}$ and $2.0 \mathrm{~m}$.

\section{A.3 Criterion of result}

Component parts shall not fall off by the impact. And there shall be no damage such as fracture, peeling off or permanent deformation, or the criterion is fail. 


\title{
Annex B
}

\author{
(Normative)
}

\section{Impact Resistance Test Method}

\section{(Cross Check with IEC 61730:2011 as MST 32 in Chapter 10.10)}

\section{B.1 Scope}

This Annex specifies the test method for testing the impact resistance of the building curtain wall by using the soft heavy body to impact the surface of the test piece.

\section{B.2 Equipment}

\section{B.2.1 Test frame}

The test frame shall be solid enough to withstand the test load, without impact on the test results, and have the clamping device meeting the test installation. The test equipment schematic diagram shall refer to Figure B.1.

\section{B.2.2 Impactor}

The impactor is a soft heavy body with total mass of $(50 \pm 0.1) \mathrm{kg}$, composed of two tires, two weights and other connection parts. The internal tire pressure shall be $(0.35 \pm 0.02) \mathrm{MPa}$. Comply with the provisions of Figure B.2.

\section{B.2.3 Equipment}

a) The hanging point of the suspension gear shall be secure enough and can adjust the overall to meet the needs of different impact positions. The stainless steel wire rope with diameter of $5 \mathrm{~mm}$ shall be used to hang the impactor. At the maximum falling height, the horizontal angle between the hanging steel wire rope and the horizontal plane of hanging point shall not be less than $14^{\circ}$;

b) When the impactor and the hanging steel wire rope are in free-state, the distance between the outer edge of the tire and the test surface shall be greater than $5 \mathrm{~mm}$ and less than $15 \mathrm{~mm}$. The geometric center of the impactor is located in the circular range of the impacted point at a radius of $50 \mathrm{~mm}$;

c) The impactor release device shall be capable of accurately positioning the lifting height of the impactor, maintaining the centerline of the impactor and the centerline of the hanging steel wire rope in the same straight line and ensuring that the impactor can freely fall after being released.

\section{B.3 Test environment}

The test sample shall be stored and tested in the non-destructive environment at the temperature of $15^{\circ} \mathrm{C} \sim 30^{\circ} \mathrm{C}$ and relative humidity of $25 \% \sim 75 \%$.

\section{B.4 Procedures}

During the test, the test sample shall be in the normal use condition, and the opening part shall be closed. 


\section{B.4.1 Impact energy}

The impact energy shall be calculated according to Formula (B.1):

$$
E=9.8 m \cdot h
$$

Where:

E - Impact energy $(\mathrm{N} \cdot \mathrm{m})$;

$\mathrm{m}$ - Mass of the impactor $(\mathrm{kg})$;

$\mathrm{h}_{1}$ - Effective drop height of the impactor (m), letter $\mathrm{C}$ as shown in Figure B.1.

\section{B.4.2 Determination the impact points}

Any part designated by the architect can be used for the impact test; generally, the following parts can be selected to test:
a) Midpoint of the adjacent points of the columns;
b) Midpoint of the beam;
c) $100 \mathrm{~mm}$ above the connection point of the column and beam;
d) Center of the curtain wall panel in the position of lower than $800 \mathrm{~mm}$ above the floor.

\section{B.4.3 Test process}

a) The test shall be conducted from the lower landing height, and then gradually increase the height, observe and record the condition of the test piece, and measure the residual deformation of the test piece. The error of the drop height shall be $\pm 20 \mathrm{~mm}$. The repeated impacts due to elasticity shall be avoided.

b) The indoor side impact resistance test shall be conducted on the test pieces with requirements for the indoor side impact resistance.

\section{B.4.4 Result judgment}

In the event of one of the following conditions, it shall be judged as unqualified:

a) The curtain wall shall be able to absorb the impact energy and maintain the original performance;

b) After the impact force disappears, the curtain wall shall be able to restore without permanent deformation;

c) The impact force shall not lead to the shedding of the curtain wall parts;

d) The curtain wall panel shall be capable of meeting the impact resistance specified in the product standard.

\section{B.5 Test report}

The test report shall include the following information:

a) Test standard;

b) Client of the test piece;

c) Type, specification, dimension, material, shape and structure of the test piece, and all related details of hardware position;

d) Storage and test conditions of the laboratory;

e) Details of the damage occurred in the test;

f) Presentation of the grading results (including the grading of double-sided inspection on the test piece);

g) Name and location of the laboratory;

h) Signature of the inspector;

i) Test date. 


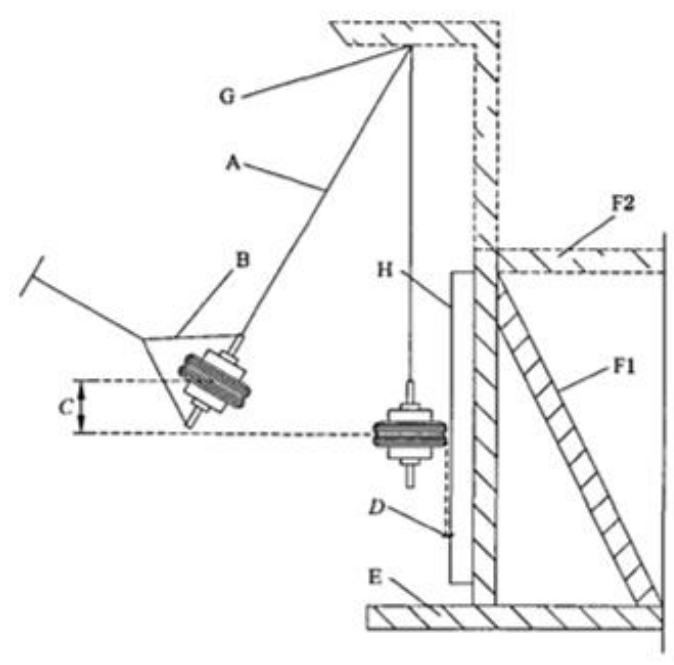
A - Hanging steel wire rope;
F1 - Supporting member;
B - Release device;
F2 - Operation supporting member;
C - Landing height;
$\mathrm{G}$ - Hanging point;
D - Distance between Soft Heavy Body and Test Piece
$\mathrm{H}$ - Test Piece.
E - Base;

Figure B.1 Soft Heavy Body Impact Test Principle

Unit: mm
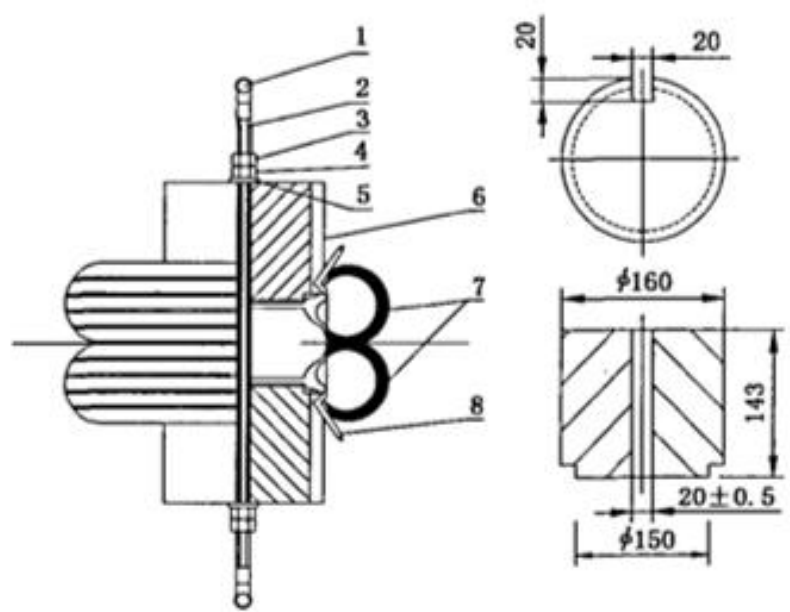

1 - Flying rings; $\quad 5$ - Adjustable pad;

2 - Screw; 6 - Weight;

3 - Lock hex nut; 7 - Tire;

4 - Hex nut; 8 - Rim.

Figure B.2 Structure of Soft Heavy Body 


\section{Annex C}

\section{(Normative)}

\section{Soft Heavy Body Impact Resistance Test}

\section{C.1 Scope}

This Annex specifies the test method for testing the soft heavy body impact resistance of the guard bar under the action of impact with shot-bag.

\section{C.2 Equipment}

\section{C.2.1 Test bench}

The test bench shall be solid, can withstand the test load, and have no impact on the test results.

\section{C.2.2 Measuring device}

The reference object shall be specified, and can be guaranteed to be vertically measured with Position B of the handrail before the experiment. Any change relative to the reference object is not allowed in the test.

\section{C.2.3 Impactor}

The impactor is a shot-bag, with weight of $45 \mathrm{~kg} \pm 0.1 \mathrm{~kg}$, of which the production requirements shall meet the requirements of GB 15763.3-2009.

\section{C.2.4 Equipment and device requirements}

The test equipment and devices shall meet the following requirements:

a) The test shall be conducted according to the requirements of GB/T 14155 with respect to the test principle, the specific test device is shown in Figure C.1, and the device in impact position shall meet the requirements of Table C.1;

b) The hanging point of the suspension gear shall be secure enough and can adjust the overall to meet the needs of different impact positions. The stainless steel wire rope with diameter of $4 \mathrm{~mm}$ shall be used to hang the shot-bag. At the maximum falling height, the horizontal angle between the hanging steel wire rope and the horizontal plane of hanging point shall not be less than $14^{\circ}$;

c) When the shot-bag and the hanging steel wire rope are in free-state, the distance between the outer edge of the shot-bag and the impact surface of the fence or handrail shall be greater than $5 \mathrm{~mm}$ and less than $15 \mathrm{~mm}$. The geometric center of the shot-bag is located in the circular range of the impacted point at a radius of $25 \mathrm{~mm}$;

d) When the test space is difficult to guarantee the lifting height of the shot-bag, the test may be conducted with the method that is the same for the impact energy.

\section{C.3 Procedures}

\section{C.3.1 Impact energy}

The impact energy shall be calculated according to Formula (C.1):

$$
E=9.8 m \cdot h_{1}
$$

Where: 
E - Impact energy, in unit of Newton Meter $(\mathrm{N} \cdot \mathrm{m})$;

$\mathrm{m}$ - Mass of the impactor, in unit of kilogram $(\mathrm{kg})$;

$\mathrm{h}_{1}$ - Effective drop height of the impact, in unit of meter (m).

\section{C.3.2 Test process}

Vertically impact Position B and Position C as shown in the Figure respectively for once, test the relative displacement of Position $\mathrm{B}$ of the handrail after $5 \mathrm{~min}$, and observe whether various connection parts are loose or not.

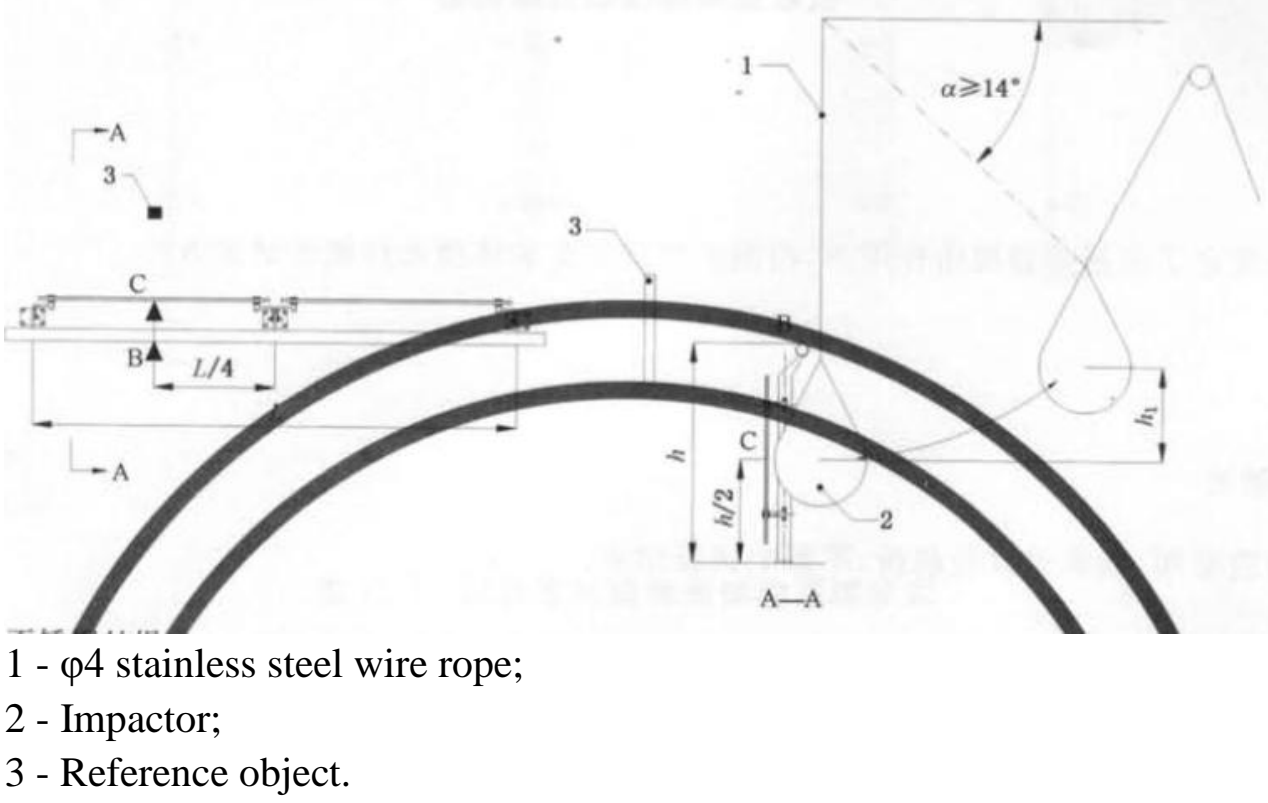

Figure C.1 Schematic diagram of soft heavy body impact resistance test devices and test principles

\section{C.3.3 Positions of resistance to soft heavy body impact}

The soft heavy body impact resistance test devices and impact positions shall meet the requirements of Table C.1.

Table C.1 Soft heavy body impact positions

\begin{tabular}{|c|c|c|c|c|}
\hline $\begin{array}{l}\text { Fence } \\
\text { Type }\end{array}$ & Sample Installation & Fence Impact & Handrail Impact & $\begin{array}{l}\text { Explanati } \\
\text { on }\end{array}$ \\
\hline $\begin{array}{l}\text { Glass } \\
\text { fence } \\
\text { Metal } \\
\text { plate } \\
\text { fence }\end{array}$ & $\begin{array}{l}\text { Handrail } \\
\text { Stand } \\
\text { colum }\end{array}$ & $\begin{array}{l}\text { Stand } \\
\text { column } \\
\text { Fence } \\
\text { Test } \\
\text { bench }\end{array}$ & \begin{tabular}{l|l} 
Fence & Im \\
Test \\
bench
\end{tabular} & $\begin{array}{l}\text { Directly } \\
\text { impact the } \\
\text { fence } \\
\text { center or } \\
\text { the central } \\
\text { part } \\
\text { between } \\
\text { two } \\
\text { columns } \\
\text { of the } \\
\text { handrail }\end{array}$ \\
\hline
\end{tabular}




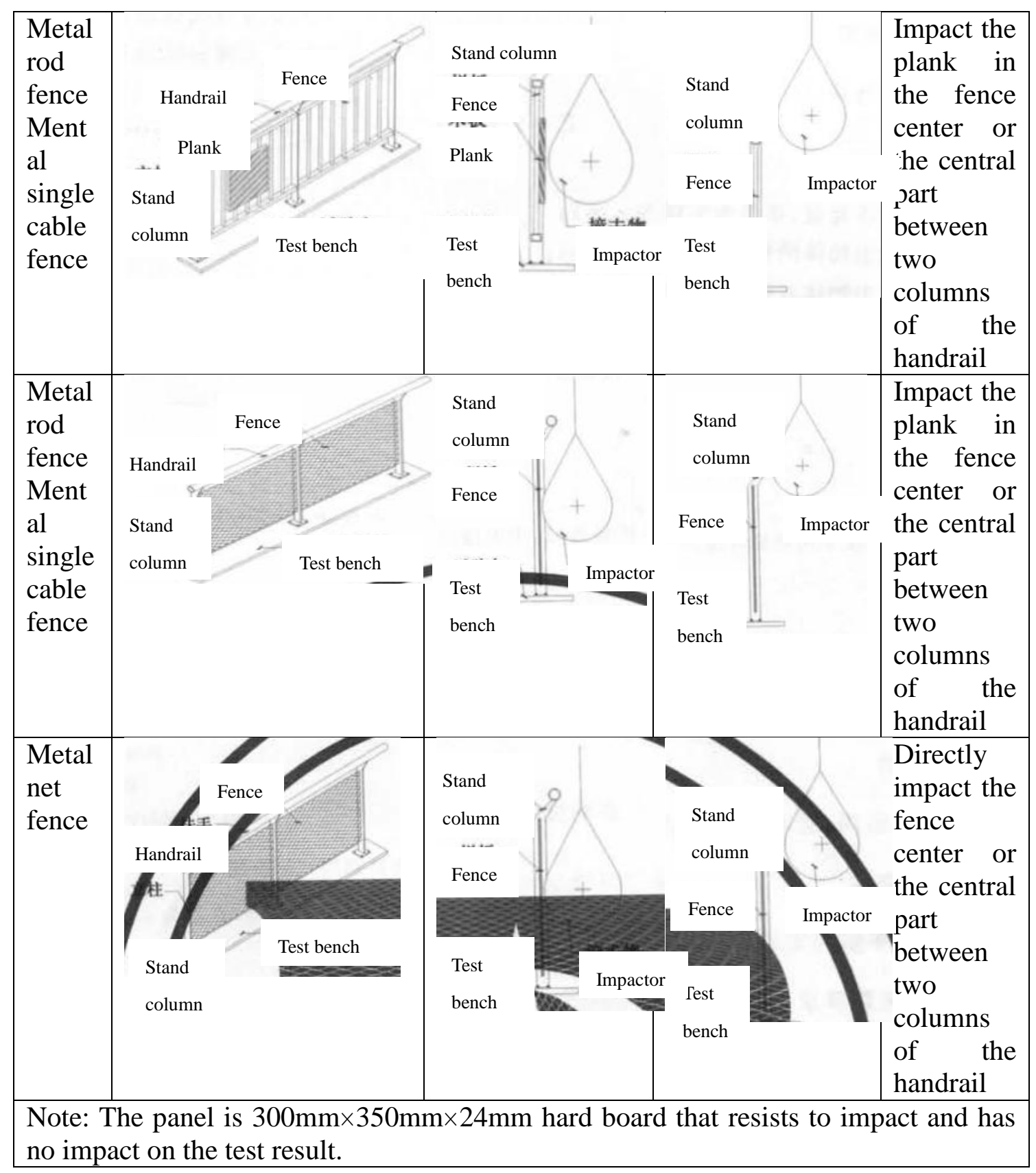

\section{C.4 Result judgment}

In the event of one of the following conditions, it shall be judged as unqualified:

a) The relative displacement of the handrail exceeds the required value of the performance;

b) Various connection parts of the fence have the phenomena of relaxation or shedding.

\section{C.5 Test report}

The test report shall include the following information:

a) Test standard;

b) Client of the test piece;

c) Main installation dimensions of the sample; 
d) Specification, material, shape and structure, surface treatment situation and other information of the sample;

e) Impactor weight and impact height;

f) Sample test description after the experiment;

g) Test date and the signature of the inspector. 


\section{Annex D}

\section{(Normative)}

\section{Hard Heavy Body Impact Resistance Test}

\section{D.1 Scope}

This Annex specifies the test method for testing the hard heavy body impact resistance of the guard bar when the hard object is used to impact the surface of fence as the test piece.

\section{D.2 Equipment}

\section{D.2.1 Test bench}

The test bench shall be solid, can withstand the test load, and have no impact on the test results.

\section{D.2.2 Impactor}

It is the solid hardened steel ball with smooth and flat surface. The hangers are attached to the ball, with the mass of $1040 \mathrm{~g} \pm 10 \mathrm{~g}$ and the diameter of $63.5 \mathrm{~mm}$.

\section{D.2.3 Equipment and device requirements}

The test equipment and devices shall meet the following requirements:

a) The hanging point of the suspension gear shall be secure enough and can adjust the overall to meet the needs of different impact positions. The stainless steel wire rope with diameter of $3 \mathrm{~mm}$ shall be used to hang the steel ball. At the maximum falling height, the horizontal angle between the hanging steel wire rope and the horizontal plane of hanging point shall not be less than $14^{\circ}$;

b) When the steel ball and the hanging steel wire rope are in free-state, the distance between the outer edge of the steel ball and the impact surface of the fence shall be greater than $5 \mathrm{~mm}$ and less than $15 \mathrm{~mm}$. The geometric center of the steel ball is located in the circular range of the impacted point at a radius of $25 \mathrm{~mm}$;

c) When the test space is difficult to guarantee the lifting height of the steel ball, the test may be conducted with the method that is the same for the impact energy.

\section{D.3 Procedures}

\section{D.3.1 Impact energy}

The impact energy shall be calculated according to Formula (D.1):

$$
E=9.8 m \cdot h_{1}
$$

Where:

E - Impact energy, in unit of Newton Meter $(\mathrm{N} \cdot \mathrm{m})$;

$\mathrm{m}$ - Mass of the impactor, in unit of kilogram $(\mathrm{kg})$;

$\mathrm{h}_{1}$ - Effective drop height of the impactor, in unit of meter $(\mathrm{m})$.

\section{D.3.2 Test process}

Impact according to the impact position as shown in Figure D.1, for which the error of the landing height is $\pm 20 \mathrm{~mm}$. Detect the fence damage and the condition of various 
connection parts of the fence after impact.

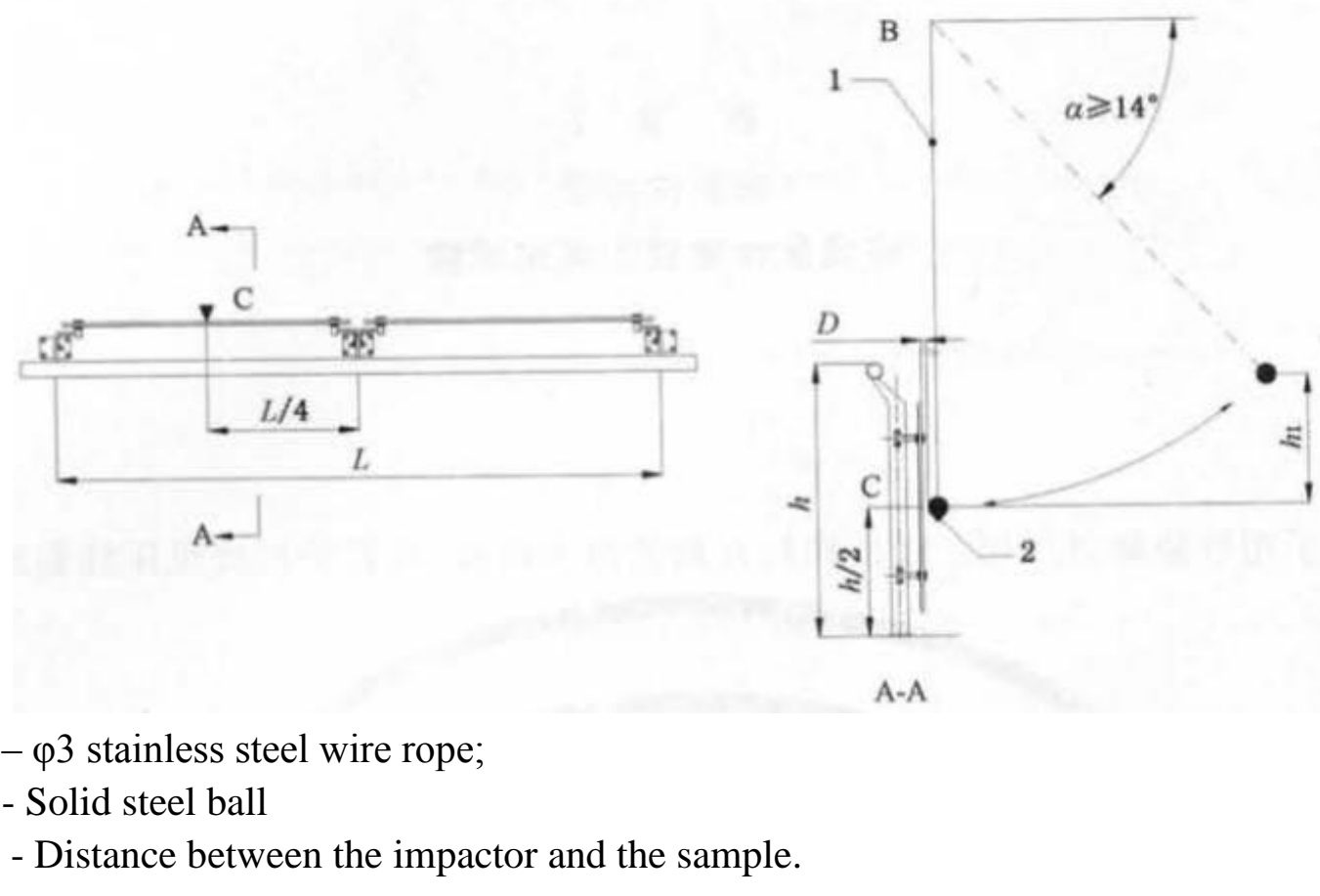

Figure D.1 Schematic diagram of hard heavy body impact resistance test devices and test principles

\section{D.4 Result judgment}

In the event of one of the following conditions, it shall be judged as unqualified:

a) There are phenomena of fragment shedding when the fence is crashed;

b) Various connection parts of the fence have the phenomena of relaxation or shedding.

\section{D.5 Test report}

The test report shall include the following information:

a) Test standard;

b) Client of the test piece;

c) Main installation dimensions of the sample;

d) Specification, material, shape and structure, surface treatment situation and other information of the sample;

e) Steel ball weight and impact height;

f) Sample test description after the experiment;

g) Test date and the signature of the inspector. 


\section{Annex E}

(Normative)

\section{Test method of freeze resistance of solar thermal Components for buildings}

\section{Or}

\section{ISO 9806 Chapter 14}

\section{E.1Test appliance and test procedure}

E.1.1 Install the solar thermal component in temperature cycling room, set the incline angle as the minimum suggested angle. If the manufacturer does not provide the minimum angle, set the horizontal angle as $30^{\circ}$.

E.1.2 Monitor the change of water temperature and room temperature. Refill the component at working pressure after every cycle.

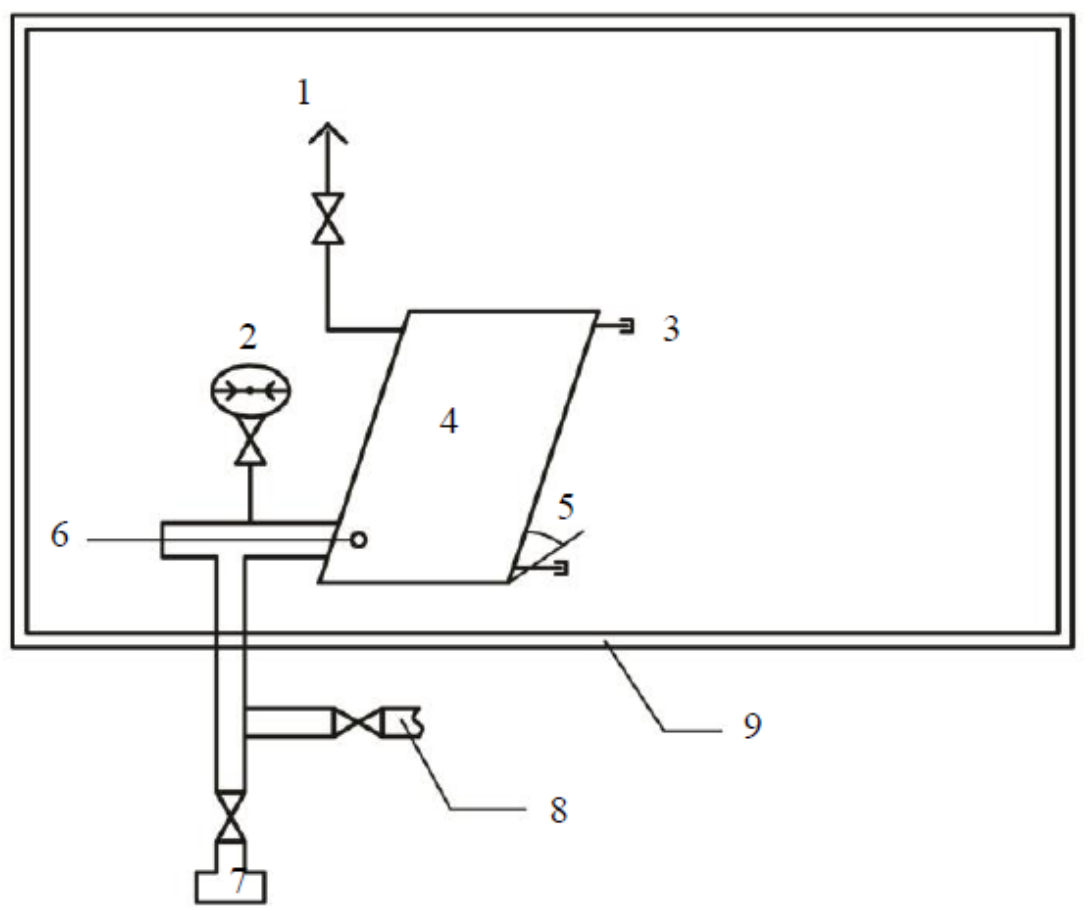

Note:

1- Drain tap;

6- Temperature sensor;

2- Pressure gage;

7- Water source;

3- Sealing fluid pipeline;

8- Drainpipe; 
5- Incline angle;

Figure E1: Diagram of hail impact test

E.1.3During the freezing process, the freeze temperature shall be $(-20 \pm 2)^{\circ} \mathrm{C}$ and the duration shall not less than $30 \mathrm{~min}$.At the unfreezingstage, thetemperature shall be greater than $10^{\circ} \mathrm{C}$, and duration shall not less than $30 \mathrm{~min}$.

E.1.4 Solar thermal component shall take 3 times of freezing-unfreezing cycle. Interval time between two tests shall be greater than $1 \mathrm{~h}$.

\section{E.2Criterion of result}

After test, refill the component at 1.5 times working pressure and maintain the pressure for $10 \mathrm{~min}$. If the component swells, deforms, leaks or breaks, the result is fail. 


\section{Annex F}

\section{(Normative)}

\section{Impermeability Test Method}

\section{F.1 Device}

Impermeable frame meeting the specification of the tested sample.

\section{F.2 Sample humidity control}

The sample shall be stored in a well-ventilated place at the temperature of $15^{\circ} \mathrm{C} \sim 30^{\circ} \mathrm{C}$ and the relative humidity of not less than $40 \%$ for at least $24 \mathrm{~h}$.

\section{F.3 Test procedures}

F3.1 Place the sample facing upward in the corresponding impermeable frame, and the deviation angle between the sample plane and the horizontal plane shall not be greater than $10^{\circ}$.

F3.2 The clearance between the frame edge and the periphery of the sample shall be not more than $3 \mathrm{~mm}$. The impermeable materials shall be used to properly seal the clearances of the sample and the frame, and the fixed orifices of the roof tile (see Figure F1).

F3.3 The water is injected into the test vessel which uses the sample as the bottom and is sealed by frame, and the water surface shall be $15 \mathrm{~mm}$ higher than the tile ridge. Such height shall be maintained in the test process. The test device is stored in the condition of temperature at $15^{\circ} \mathrm{C} \sim 30^{\circ} \mathrm{C}$ and the relative humidity of not less than $40 \%$ for $24 \mathrm{~h}$.

\section{F4 Results and assessment}

If it is observed that there are no water droplets at the back of the tested sample, then the impermeability is qualified. If there are water droplets at the back of one or more samples in the group, then the impermeability is unqualified. 


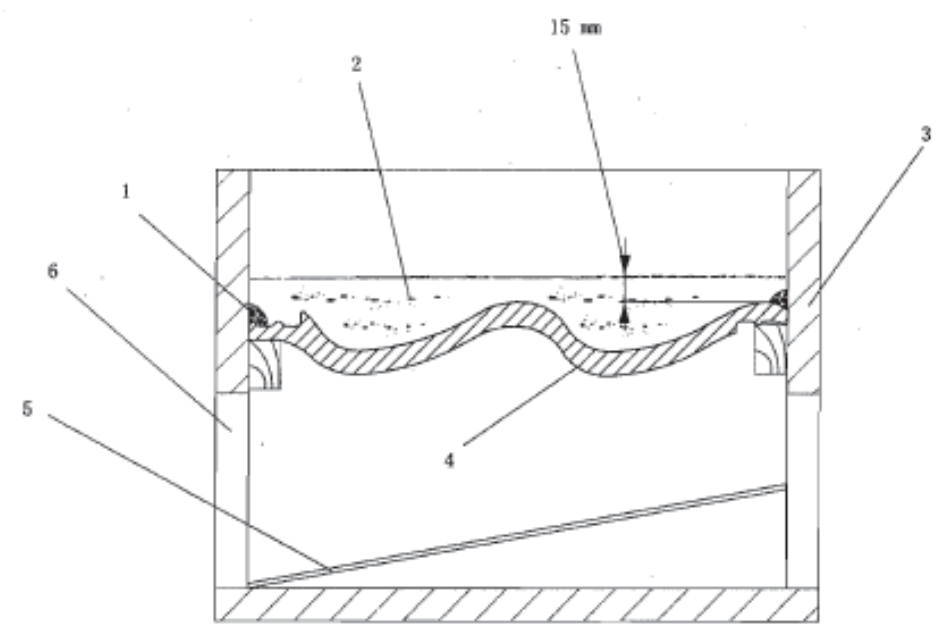

1 - Sealing material;

2 - Water;

3 - Impermeable frame;

4 - Sample;

5 - Lens;

6 - Observation hole.

Figure F.1 Impermeability Test Device Schematic Diagram 


\section{Annex G}

\section{(Normative)}

\section{Soft Heavy Body Impact Resistance Test}

\section{G.1 Scope}

This Annex applies to the snow load resistance test on roller shutters having the inclined angle with horizontal plane of less than $60^{\circ}$, sunshade (except for the fixed sunshade), venetian blinds and other external shading products.

\section{G.2 Test}

\section{G.2.1 Testing equipment}

G.2.1.1 The horizontal loading equipment is shown in Figure G1 and shall meet the following requirements:

a) Displacement sensor: accuracy of Level 1 and resolution of $0.01 \mathrm{~mm}$

b) Time recorder: accuracy of Level 1 and resolution of 1s;

c) Balance: accuracy of Level 1 and resolution of $1 \mathrm{~g}$.

G.2.1.2 The vertical loading equipment is shown in Figure G2, and shall meet the following requirements: 


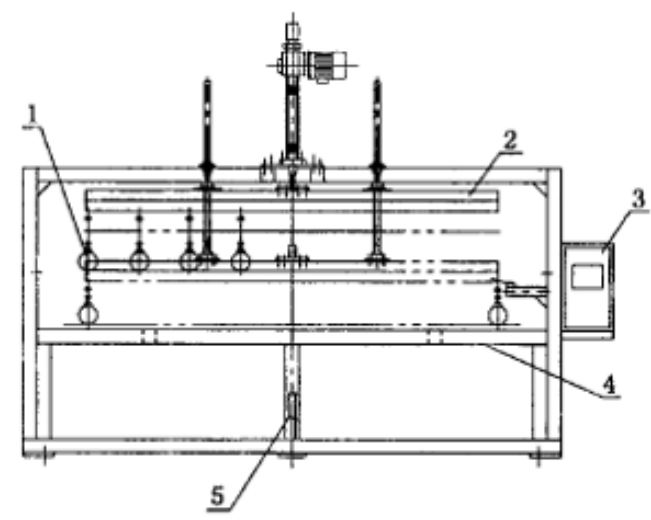

Note:

1 - Loading bag;

2 - Loading frame;

3 - Control box;

4 - Test piece rack;

5 - Displacement sensor.

Figure G.1 Schematic diagram of horizontal loading device

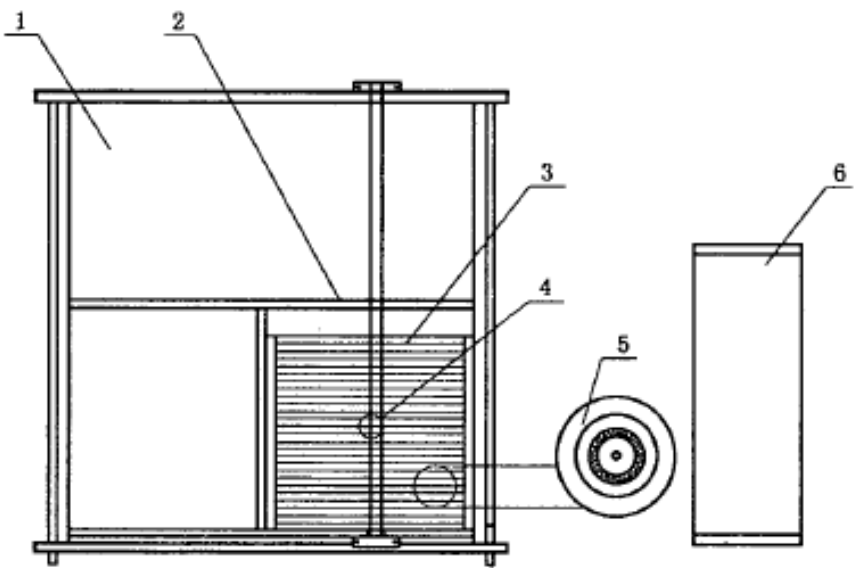

Note:

1 - Wind pressure box frame;

2 - Static pressure box;

3 - Shading products;

4 - Displacement sensor;

5 - Fan system;

6 - Control system.

Figure G.2 Schematic diagram of vertical loading equipment

\section{G.2.2 Sample installation}

G.2.2.1 The specifications, types and materials of the tested pieces shall be consistent with the drawings provided by the manufacturer and shall not be fitted with any special accessories or other measures assisting in carrying.

G.2.2.2 When the snow load resistance test is separately conducted on the shading product, the shading product and the actuating device shall be installed on the rigid frame together according to the requirements of the product specification.

G.2.2.3 When the snow load resistance test is conducted on the shading product and 
the glass window jointly, the sample installation method is the same as that of G2.2.2, and meanwhile the rigid frame shall be installed with a rigid panel representing the glass window, which is arranged in the place of $1.2 \mathrm{~d}$ away from the inner surface of the shading product. The deformation of the rigid panel and rigid frame under the action of the load shall not be greater than 1/300. In the case of vertical loading, 10 holes with diameter of $5 \mathrm{~mm}$ shall be evenly arranged on a rigid panel per square meter.

\section{G.2.3 Test load}

The test load values are determined according to Table G1 or Table G2.

Table G.1 Load value during horizontal placement of shading products

\begin{tabular}{|c|c|}
\multicolumn{2}{c}{ Unit: $\mathrm{N} / \mathrm{m}^{2}$} \\
\hline Rated Test Load $\mathrm{P}_{1}$ & $\mathrm{P}_{1} \geq \mathrm{P}$ \\
\hline Safe Test Load $\mathrm{P}_{2}$ & $\mathrm{P}_{2} \geq 1.2 \mathrm{P}$ \\
\hline
\end{tabular}

Note: $\mathrm{P}$ is the rated load of the shading product, of which the value is based on the product design or the provisions of JG/T 274.

Table G.2 Load value during vertical placement of shading products

\begin{tabular}{|l|c|}
\hline Rated Test Load $\mathrm{P}_{1}$ & $\mathrm{P}_{1} \geq \mathrm{P}+\mathrm{P}_{0}$ \\
\hline Safe Test Load $\mathrm{P}_{2}$ & $\mathrm{P}_{2} \geq 1.2 \mathrm{P}+\mathrm{P}_{0}$ \\
\hline
\end{tabular}

Note 1: $\mathrm{P}$ is the rated load of the shading product, of which the value is based on the product design or the provisions of JG/T 274.

Note 2: $\mathrm{P}_{0}$ is the dead weight of the shading product / area of the shading product.

\section{G.2.4 Loading method}

G.2.4.1 In case of horizontal loading method for testing, the shading sample shall be placed horizontally. The loading points of uniformly distributed load simulated per square meter shall not be less than 9, and the outermost loading point shall not be greater than $150 \mathrm{~mm}$ from the edge of the shading product.

G.2.4.2 In case of vertical loading method for testing, the shading sample shall be placed vertically, and a layer of polyester film or similar material shall be used to cover at the back of the sample. The loading error shall not be greater than $\pm 5 \%$.

\section{G.2.5 Test procedures}

G.2.5.1 The separate snow load resistance test on the shading products shall be conducted according to the following procedures:

a) Before applying the load, the operating force shall be tested according to JG/T 242 for the manual shading products, and the opening and closing, stretching and retraction circulating operation shall be conducted for at least once for the electric shading products;

b) Install the shading product. In case of the horizontal installation, record the initial location of the geometric center of the sample; in case of vertical installation, apply $\mathrm{P}_{0}$. When the shading products are installed horizontally, record the initial position of the geometric center; when the shading products are installed vertically, apply $\mathrm{P}_{0}$, and record the initial position of the geometric 
center.

c) Apply the rated test load to the sample at a constant speed of less than $2 \mathrm{~m} / \mathrm{min}$ for duration of $5 \mathrm{~min}$, and measure the maximum displacement of the geometric center of the sample;

d) After unloading for $2 \mathrm{~min}$, for the electric shading products, record the damage and residual deformation, etc., complete the opening and closing, stretching and retraction circulating operation for once and record the existence of malfunction; for manual shading products, record the damage and residual deformation, etc., test the operating force according to JG/T 242, and record the changes of the operating force;

e) Apply the safe test load to the sample at a constant speed of less than $2 \mathrm{~m} / \mathrm{min}$ for duration of $5 \mathrm{~min}$, and record the changes and damage of the sample.

G.2.5.2 The joint snow load resistance test on shading product and the glass window shall be conducted according to the following procedures:

a) Before applying the load, the operating force shall be tested according to JG/T 242 for the manual shading products, and the opening and closing, stretching and retraction circulating operation shall be conducted for at least once for the electric shading products;

b) Apply the rated test load for duration of $5 \mathrm{~min}$, and observe whether the sample is in contact with the rigid panel. If the sample is in contact with the rigid panel, the test shall be conducted by degradation;

c) After unloading for $2 \mathrm{~min}$, for the electric shading products, record the damage and residual deformation, etc., complete the opening and closing, stretching and retraction circulating operation for once and record the existence of malfunction; for manual shading products, record the damage and residual deformation, etc., test the operating force according to JG/T 242, and record the changes of the operating force;

d) Apply the safe test load to the sample at a constant speed of less than $2 \mathrm{~m} / \mathrm{min}$ for duration of $5 \mathrm{~min}$, and record the changes and damage of the sample.

G.2.5.3 The change rate $\mathrm{V}$ of the operating force of the manual shading product shall be calculated according to Formula (1):

$$
V=\left[\frac{F_{\mathrm{e}}}{F_{\mathrm{i}}}-1\right] \times 100 \%
$$

Where:

$\mathrm{V}$ - Operating force change rate;

$\mathrm{F}_{\mathrm{e}}$ - Operating force after detection, in unit of Newton $(\mathrm{N})$;

$F_{i}$ - Initial operating force, in unit of Newton $(N)$.

G.2.5.4 After applying the safe test load, observe and record the following conditions:

a) Whether the curtain slice or plate is out of the guide rail;

b) Whether the curtain slice, plate or guide rod are broken.

\section{G.3 Test report}

The test report shall include the following contents: 

a) Client information;
b) Whether the sample is submitted for inspection or sampled for inspection;
c) Product name, specification and model;
d) Test standard;
e) Loading method;
f) Damage conduction (for example, whether the curtain slice and plate are out of the guide rail; whether the curtain slice, plate or guide rail have phenomena of permanent deformation and breakage, etc.);
g) Test results;
h) Other instructions. 